\title{
USING IRRADIATION TECHNIQUE OF GAMMA RAYS TO IMPROVE COMPOST QUALITY
}

\author{
E.A. Abou Hussien ${ }^{(1)}$, B.Y. EL Koumey(1), E. A. Kotb(2) \\ and A.M.A. Hessien ${ }^{(1)}$ \\ (1) Soil Sci. Dept. Fac. of Agri. Menoufia Univ. Egypt. \\ (2) Soil and water Dept, Nuclear Res. Center, EAEA.
}

Received: Feb. 24, 2019

Accepted: May 7, 2019

\begin{abstract}
Composts produced from leucaena leaves (LL) poultry manure (PM), sugarcane bagasse (SB) were studied. LL were used also irradiated (ILL) with gamma rays at doses of 2.5, 5.0 and $10.0 \mathrm{kGy}$ (ILL). LL, ILL (2.5 kGy), ILL (5 kGy), ILL(10 kGy), PM + SB+ ULL, PM+ SB+ ILL(2.5 kGy), PM+SB+ ILL (5 kGy) and PM+SB+ ILL (10 KGy) were prepared representing $C 1, C 2, C 3, C 4, C 5, C 6, C 7$ and $C 8$ treatments respectively. During composting period (60 days) samples of each pile were taken at $0,15,30,45$ and 60 days of composting and analyzed for their content of organic $C(O C), N, P$ and $K$. OC decreased with the increase in composting period and with irradiation. $P M$ and $S B$ applications combined with either un- irradiated or irradiated $L L$ increased $N, P$ and $K$ with the increase composting period and irradiation doses of gamma rays.
\end{abstract}

Key words: Compost, Composting period, Chemical composition, Gamma rays and Leucaena leaves.

\section{INTRODUCTION}

Composts contain a considerable variety of macro- and micro nutrients. Although often seen as good sources of $\mathrm{N}, \mathrm{P}$, and $\mathrm{K}$, composts also contains $\mathrm{S}$, $\mathrm{Ca}$, and $\mathrm{Mg}$, as well as micro nutrients. Because composts contain relatively stable sources of organic matter. These nutrients are supplied in a slow-release form. Compost is usually applied at much higher rates than inorganic fertilizer; thus it can have a significant cumulative effect on nutrient loading and availability. Compost made from biosolids often has a higher $N$ and $P$ content than compost made from animal manures and yard trimmings (Alexander, 2001 and Nada 2011). Elvire et al., (1998) reported that 55 to $100 \%$ increases in total $\mathrm{N}$ due to mineralization of organic matter. Warman and Anglopez (2002) observed 42 to $85 \%$ increases in total $N$ in three vermin composts after 45,68 and after 90 days. However, total $\mathrm{N}$ returned to levels only slightly above initial contents of 13,24 , and $20 \mathrm{~g} \mathrm{~kg}^{-1}$. Mineral $\mathrm{N}$ content in composts is generally low, since $\mathrm{N}$ is partly lost during composting due to $\mathrm{NH}_{3}$ volatilization (Zwart, 2003). Total $\mathrm{N}$ is not readily available to plants and can be mineralized, and then potentially taken up by the plants, immobilized, denitrified, volatilized, fixed within the clay minerals and/or leached.

Phosphorus in composts generally range from $<0.4$ to $>23 \mathrm{~g} \mathrm{~kg}^{-1}$ (He et al., 1995 and Vogtmann et al., 1993), depending on compost source. Biosolids generally contain greater $P$ content than most feedstocks. However, a varying proportion of $P$ in bio-solids is in organic forms, which are less available to plants (He et al., 2000). Lee (2016) reported availability of $N$ and $P$ from various composted wastes. Most municipal solid waste composts in U.S. and European countries have 2 to $6 \mathrm{~g} \mathrm{P}$ $\mathrm{kg}^{-1}$ with a mean of $3.3 \mathrm{~g} \mathrm{~kg}^{-1}$. Such $P$ contents are about 2 to 10 times greater than total $\mathrm{P}$ in most arable soils (He et al., 2001). Application of compost can increase available $P$ in soil. Organic $P$ in 
composts made of plant residues is readily decomposed to release available to plants. Availability of $P$ in composts ranges from 20 to $40 \%$ of total $P$ (Vogtmann et al., 1993). Biosolids/ sawdust compost applied to a sandy soil at 7.5 to $30 \mathrm{~g} \mathrm{~kg}^{-1}$ had little effect on organic $P$ and its labile form (Coutinho et al., 1997 and Nada, 2011).

Contents of $\mathrm{K}$ in composts vary from 0.7 to $>12 \mathrm{~g} \mathrm{~kg}^{-1}$, with a mean of $5.4 \mathrm{~g}$ $\mathrm{Kg}^{-1}(\mathrm{He}$ et al., 2001). Such range is lower than the $K$ in plant (8 to $\left.35 \mathrm{~g} \mathrm{~kg}^{-1}\right)$. Potassium is highly mobile in plants at all levels (Marschner, 1995). Part of $K$ in plant materials may be lost during composting. Composts can be alternative sources of $\mathrm{K}$ for crops. Plant availability of $\mathrm{K}$ in composts can be more than $85 \%$ of their total K (Vogtmann et al., 1993).

\section{MATERIALS AND METHODS}

Four organic wastes varying in their origin and chemical composition were used. These organic wastes were:

a- Poultry manure (PM) taken from a private farm.

b- Sugarcane bagasse (SB) collected from different sources.

C- Leaves of leucaena trees collected from a farm under drip irrigation (Unirradiated leaves).

d- Irradiated leaves of leucaena trees (ILL) where a portions of the collected and irradiated leaves using gamma rays of doses $0,2.5,5.0$ and $10 \mathrm{kGy}$ were used.

These organic residue were air-dried and shredded into small pieces of about $1 \mathrm{~cm}$ diameter. Properties the residues are shown in Table 1.

Table 1: Chemical composition and total nutrients content of the raw materials of the used organic residues.

\begin{tabular}{|c|c|c|c|c|c|c|c|}
\hline \multirow{2}{*}{\multicolumn{2}{|c|}{$\begin{array}{l}\text { Properties } \\
\text { and units }\end{array}$}} & \multicolumn{6}{|c|}{ Organic residues } \\
\hline & & P M & S B & $\begin{array}{c}\text { I LL } \\
(0.0 \\
\text { KGY) }\end{array}$ & $\begin{array}{c}\text { ILL } \\
(2.5 \mathrm{KGY})\end{array}$ & $\begin{array}{c}\text { ILL } \\
\text { (5.0KGY) }\end{array}$ & $\begin{array}{c}\text { ILL } \\
(10.0 \mathrm{KGY})\end{array}$ \\
\hline \multicolumn{2}{|c|}{$\mathrm{pH}$} & 6.8 & 4.2 & 6.9 & 6.7 & 6.5 & 6.2 \\
\hline \multicolumn{2}{|c|}{$E C^{* *}\left(d_{S m^{-1}}\right)$} & 21.3 & 0.03 & 0.2 & 0.21 & 0.24 & 0.27 \\
\hline \multicolumn{2}{|c|}{ OM (\%) } & 6.29 & 4.85 & 8.22 & 7.8 & 7.1 & 5.95 \\
\hline \multicolumn{2}{|c|}{$\mathrm{C} / \mathrm{N}$ ratio } & 12.1 & 104.3 & 23.5 & 20.8 & 17.75 & 13.8 \\
\hline \multirow{7}{*}{ 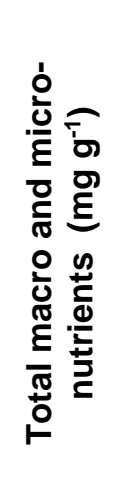 } & $\mathbf{N}$ & 52 & 4.65 & 35 & 37.5 & 40 & 43.6 \\
\hline & $\mathbf{P}$ & 20.2 & 9.9 & 17.7 & 17.9 & 18.5 & 18.9 \\
\hline & K & 20 & 3.8 & 9.3 & 9.5 & 9.8 & 10.2 \\
\hline & $\mathrm{Fe}$ & 0.461 & 0.284 & 0.165 & 0.195 & 0.258 & 0.315 \\
\hline & Mn & 0.89 & 0.045 & 0.035 & 0.038 & 0.042 & 0.048 \\
\hline & $Z n$ & 0.92 & 0.019 & 0.028 & 0.031 & 0.035 & 0.039 \\
\hline & $\mathrm{Cu}$ & 0.091 & 0.022 & 0.043 & 0.046 & 0.051 & 0.057 \\
\hline
\end{tabular}

* In 1:10 soil: water sups. ** in soil paste extract. PM : Poultry manure, SB : sugarcane bagass, LL : leucaena leaves (LL), ILL: Irradiated leucaena leaves (ILL). 
The experiment consisted of 8 treatments of composting process as shown in Table 2. The design was a randomized complete block, factorial with 3 replicates. Factor 1 was the compost (8 treatments) and factor 2 was the composting period (5 period).

Composting was carried out in containers with $50 \times 50 \times 50 \mathrm{~cm}$. The materials were shredded into fine pieces of about $1 \mathrm{~cm}$ diameter. Each pile was mixed with $100 \mathrm{~g}$ calcium carbonate, 500 $\mathrm{g}$ super phosphate and $500 \mathrm{~g}$ of ammonium sulfate as chemical activator, Along with bacterial strain was added as microbial activators. The mixture of each container was mixed well gently and arranged in equal six layers within the container.

The organic residue materials were moistened by water up to $50-60 \%$ of its water holding capacity (WHC) and left for decomposition up to 60 days. The piles of materials were turned upside down every ten days. After each turn off samples of each pile were taken for analysis. Maturity time for the organic materials was obtained after 60 days (Abou-Hussein et al., 2017). Samples were taken at intervals of $0,15,30,45$ and 60 days for analysis.

The relative change (RC) of yield (grains and straw) was calculated according to Khalil et al., (2015) as follows:

$R C=\frac{\text { dry matter yield of treated plants }- \text { dry matter yield of untreated plants }}{\text { dry matter of untreated plants }} \times 100$

The agronomical efficiency (AE) was calculated according to Sisworo et al., (1990) as follows:

$A E=\frac{\text { dry matter yield of treated plants-dry matter yield of untreated plants }}{\text { added compost ton } \text { fed-1 }}$

The harvest index (\%) of yield was calculated according to Khalil et al., (2015) as follows:

Harvest index $(\%)=\frac{\text { grains yeild }(\text { ton fed }-1)}{\text { biological yeild }(\text { ton fed }-1)} \times 100$

Table 2: Materials and material mixtures used in making composts.

\begin{tabular}{|c|c|}
\hline $\begin{array}{l}\text { Compost } \\
\text { code }\end{array}$ & Mixture rates of the used organic materials \\
\hline C1 & $0 \mathrm{~kg} \mathrm{PM}+0 \mathrm{~kg} \mathrm{SB}+15 \mathrm{~kg}$ ILL $0.0 \mathrm{KGy}$ \\
\hline C2 & 0 kg PM + 0 kg SB + 15 kg I LL 2.5 KGy \\
\hline C3 & $0 \mathrm{~kg} \mathrm{PM}+0 \mathrm{~kg} \mathrm{SB}+15 \mathrm{~kg} \mathrm{I} \mathrm{LL} 5.0 \mathrm{KGy}$ \\
\hline C4 & $0 \mathrm{~kg} \mathrm{PM}+0 \mathrm{~kg} \mathrm{SB}+15 \mathrm{~kg}$ I LL 10.0KGy \\
\hline C5 & $5 \mathrm{~kg} \mathrm{PM}+5 \mathrm{~kg} \mathrm{SB}+5 \mathrm{~kg}$ ILL $0.0 \mathrm{KGy}$ \\
\hline C6 & $5 \mathrm{~kg} \mathrm{PM}+5 \mathrm{~kg} \mathrm{SB}+5 \mathrm{~kg}$ I LL $2.5 \mathrm{KGy}$ \\
\hline C7 & $5 \mathrm{~kg} \mathrm{PM}+5 \mathrm{~kg} \mathrm{SB}+5 \mathrm{~kg}$ I LL 5.0 KGy \\
\hline $\mathrm{C8}$ & $5 \mathrm{~kg} P M+5 \mathrm{~kg}$ SB $+5 \mathrm{~kg}$ I LL $10.0 \mathrm{KGy}$ \\
\hline
\end{tabular}




\section{RESULTS AND DISCUSSION}

\section{Organic carbon (OC) content}

Data in Table 3 show that, increasing period of composting process was associated by a significant decrease of $O C$. The relative changes "RC" were negative along the 60 dayes of composting. This can be mainly attributed to chemical and biological transformation during composting (Stevenson, 1994). Elgezairi (2016) and Abou.Hussien et al. (2017) and sisouane et al. (2017) obtained results with composting indicating a decrease in $\mathrm{OC}$ with composting. Irradiation decreased $O C$ in the composts produced from LL alone and its mixture with PM and SB, particularly with increased dose of irradiation with time. At 30 days of composting period RC of compost content of $O C$ in relation with irradiation doses were $-9,-5$ and $-7 \%$ for C2 , C3 and
C4 irradiated by 2.5, 5 and 10 KGy respectively. Applying irradiation increased decomposition rate and maturing degree of produced compost. This effect may be attributed to the degradation effect of gamma rays on the tissues of organic materials ( Fan et al, 2018). These results agree with those obtained by Hagemann et al. (2018). At all composting periods and with the three doses of gamma rays composts from C2,C3 and C4 LL mixed and irradiate C6, C7and C8 had OC compared with those in the composts of $\mathrm{C} 1$ and $\mathrm{C} 5$. This may be attributed to presence bio - and chemical activates in the PM and SB which would to increase decompositing (Stevenson, 1994). Gohar (2011) and Abou Hussien et al (2016) noted a clear effect of raw materials sources on the produced content of $\mathrm{OC}$.

Table 3: Effect of raw organic materials source and irradiation using gamma rays on produced compost content (\%) of organic carbon (OC) and its relative change "RC" (\%) at different composting periods (day).

\begin{tabular}{|c|c|c|c|c|c|c|c|c|c|c|}
\hline \multirow{3}{*}{$\begin{array}{l}\text { Compost } \\
\text { type } \\
\text { (CT) }\end{array}$} & \multicolumn{9}{|c|}{ Composting period " CP ": (Day) } & \multirow{3}{*}{$\begin{array}{c}\text { Mean } \\
\%\end{array}$} \\
\hline & \multirow{2}{*}{$\begin{array}{l}0 \\
\%\end{array}$} & \multicolumn{2}{|c|}{15} & \multicolumn{2}{|c|}{30} & \multicolumn{2}{|c|}{45} & \multicolumn{2}{|c|}{60} & \\
\hline & & $\%$ & $\begin{array}{c}\text { RC } \\
\%\end{array}$ & $\%$ & $\begin{array}{c}\text { RC } \\
\%\end{array}$ & $\%$ & $\begin{array}{c}\text { RC } \\
\%\end{array}$ & $\%$ & $\begin{array}{c}\text { RC } \\
\%\end{array}$ & \\
\hline C1 & 27.34 & 27.18 & & 27.10 & & 26.49 & & 21.74 & & 25.97 \\
\hline $\mathrm{C} 2$ & 26.41 & 25.79 & -5 & 24.56 & -9 & 22.34 & -16 & 21.73 & 0 & 24.17 \\
\hline C3 & 26.26 & 25.71 & -5 & 25.64 & -5 & 25.26 & -5 & 24.64 & 13 & 25.50 \\
\hline C4 & 25.71 & 25.49 & -6 & 25.10 & -7 & 24.86 & -6 & 21.73 & 0 & 24.58 \\
\hline C5 & 26.44 & 26.38 & -3 & 26.34 & -3 & 26.00 & -2 & 21.13 & -3 & 25.26 \\
\hline C6 & 26.29 & 26.28 & -3 & 26.25 & -3 & 25.64 & -3 & 20.63 & -5 & 25.02 \\
\hline $\mathrm{C7}$ & 26.24 & 25.88 & -5 & 25.63 & -5 & 24.26 & -8 & 19.88 & -9 & 24.38 \\
\hline $\mathrm{C} 8$ & 25.50 & 25.31 & -7 & 25.28 & -7 & 23.95 & -10 & 19.50 & -10 & 23.91 \\
\hline Mean & 26.27 & 26.00 & & 25.74 & & 24.85 & & 21.37 & & \\
\hline \multicolumn{3}{|l|}{ LSD at 0.05} & \multicolumn{2}{|c|}{ CP: 0.81} & \multicolumn{5}{|c|}{ CT $\times C P: 2.30$} & \\
\hline
\end{tabular}

- C1 up to C8 are leucaena leaves (LL), irradiated leucaena leaves ( ILL at 2.5 kGy,), irradiated leucaena leaves ( ILL at $5 \mathrm{kGy}$ ), irradiated leucaena leaves ( ILL at $10 \mathrm{kGy}$ ), 1:1:1 mixture of poultry manure (PM) : sugarcane bagasse (SB) : LL ; mixture PM:SB:ILL at 2.5 kGy, mixture PM:SB:ILL at $5 \mathrm{kGy}$; , mixture PM:SB:ILL at $10 \mathrm{kGy}$. 


\section{Total N:}

The presented data in Table (4) increasing in both composting periods and irradiation doses of gamma rays resulted in a significant increases in RC values of $\mathrm{N}$ were positive and increased with the increase in composting period and irradiation doses. This indicates decreases of $\mathrm{pH}$ with the increase in the composting time. Elgezairy (2016) and Abou Hussien et al (2017) obtained results indicating increased $\mathrm{N}$ in compost produced from maize stalk. jain et al (2018) pointed out that irradiation of organic wastes using gamma rays increased decomposition of their composts. At 30 days of composting, RC of total $\mathrm{N}$ content were 4,12 and $40 \%$ for $\mathrm{C2}, \mathrm{C} 3$ and C4 irradiated by 2.5, 5.0 and $10.0 \mathrm{KGy}$ compared with $\mathrm{C} 1$, respectively. This indicate that organic residues characterized by hardness of their tissues may be irradiated to increase their decomposition ( liu et al., 2018).

Composts $\mathrm{C5}$ to $\mathrm{C} 8$ have high contents of $\mathrm{N}$. This reflect the high $\mathrm{N}$ content in PM and SB. Materials of high $\mathbf{N}$ produce compost of high N ( Stevenson,
1994). Gohar (2011) mentioned that, total $\mathrm{N}$ in compost depended on the chemical composition of the composted organic materials. Iqbal et al (2015) obtained indicating high $\mathrm{N}$ content in compost $\mathrm{C} / \mathrm{N}$ ratio. kononova (1966) and Stevenson (1994) mentioned that, $C / N$ ratio of organic matter and their composts may be used to organic substances. Data in Table 5 show that $\mathrm{C} / \mathrm{N}$ ratio depend on the source of composted residues. Increasing composing period and irradiation dose resulted in a decrease of $\mathrm{C} / \mathrm{N}$ ration of the composts. This results from the decrease in the compost content of total $O C$ and increase in the content of total N, PM and SB application with un-irradiation and irradiation of leucaena leaves tended to decrease $\mathrm{C} / \mathrm{N}$ ration of the produced composts. The rate effect of composting period, irradiation dose and sources of the composted organic materials may be defined and cleared from the calculated $\mathrm{RC}(\%)$ values of C/N ratio, Gohar (2011); Elgezeiry (2016) and Abou Hussien et al (2017) obtained results indicating narrow $\mathrm{C} / \mathrm{N}$ ratio in composts.

Table 4: Effect of raw organic materials source and irradiation using gamma rays on total $\mathrm{N}$ in compost and its relative change "RC" (\%) at different composting periods.

\begin{tabular}{|c|c|c|c|c|c|c|c|c|c|c|}
\hline \multirow{3}{*}{$\begin{array}{l}\text { Compost } \\
\text { type } \\
\text { (CT) }\end{array}$} & \multicolumn{9}{|c|}{ Composting period " CP ": (Day) } & \multirow{3}{*}{$\begin{array}{c}\text { Mean } \\
\%\end{array}$} \\
\hline & \multirow{2}{*}{$\begin{array}{l}0 \\
\%\end{array}$} & \multicolumn{2}{|c|}{15} & \multicolumn{2}{|c|}{30} & \multicolumn{2}{|c|}{45} & \multicolumn{2}{|c|}{60} & \\
\hline & & $\%$ & $\begin{array}{c}\mathrm{RC} \\
\%\end{array}$ & $\%$ & $\begin{array}{c}\text { RC } \\
\%\end{array}$ & $\%$ & $\begin{array}{c}\text { RC } \\
\%\end{array}$ & $\%$ & $\begin{array}{c}\text { RC } \\
\%\end{array}$ & \\
\hline C1 & 1.33 & 1.61 & & 1.74 & & 1.95 & & 1.99 & & 1.72 \\
\hline C2 & 1.53 & 1.61 & 0 & 1.81 & 4 & 1.95 & 0 & 2.01 & 1 & 1.78 \\
\hline C3 & 1.86 & 1.95 & 21 & 1.95 & 12 & 2.03 & 4 & 2.11 & 6 & 1.98 \\
\hline C4 & 1.89 & 2.15 & 33 & 2.44 & 40 & 3.16 & 62 & 3.26 & 64 & 2.58 \\
\hline C5 & 1.60 & 1.84 & 14 & 1.95 & 12 & 1.96 & 1 & 2.10 & 6 & 1.89 \\
\hline C6 & 1.58 & 2.20 & 36 & 2.41 & 39 & 2.65 & 36 & 3.11 & 56 & 2.39 \\
\hline C7 & 1.79 & 2.48 & 54 & 2.54 & 46 & 3.19 & 63 & 3.26 & 64 & 2.65 \\
\hline C8 & 1.95 & 2.54 & 57 & 2.64 & 52 & 3.28 & 68 & 3.33 & 67 & 2.75 \\
\hline Mean & 1.69 & 2.05 & & 2.18 & & 2.52 & & 2.65 & & \\
\hline \multicolumn{3}{|c|}{ LSD at 0.05} & \multicolumn{2}{|c|}{ CP: 0.07} & $\mathrm{TT} \times \mathrm{Cl}$ & 0.20 & & & & \\
\hline
\end{tabular}

See footnotes of table 3 for treatments description. 
E.A. Abou-Hussien, et al.,

Table 5: Effect of raw organic materials source and irradiation using gamma rays on produced compost $\mathrm{C} / \mathrm{N}$ ratio and its relative change "RC" (\%) at different composting periods.

\begin{tabular}{|c|c|c|c|c|c|c|c|c|c|c|}
\hline \multirow{3}{*}{$\begin{array}{c}\text { Compost } \\
\text { type } \\
\text { (CT) }\end{array}$} & \multicolumn{9}{|c|}{ Composting period " CP ": (Day) } & \multirow{3}{*}{$\begin{array}{l}\text { Mean } \\
\text { Value }\end{array}$} \\
\hline & \multirow{2}{*}{$\begin{array}{c}0 \\
\text { Value }\end{array}$} & \multicolumn{2}{|c|}{15} & \multicolumn{2}{|c|}{30} & \multicolumn{2}{|c|}{45} & \multicolumn{2}{|c|}{60} & \\
\hline & & Value & RC \% & Value & RC \% & Value & RC \% & Value & RC \% & \\
\hline C1 & 20.63 & 16.85 & & 15.59 & & 13.58 & & 10.93 & & 15.57 \\
\hline C2 & 17.31 & 15.99 & -5 & 13.55 & -13 & 11.45 & -15 & 10.79 & -1 & 13.81 \\
\hline C3 & 14.10 & 13.18 & -21 & 13.15 & -15 & 12.47 & -8 & 11.66 & 6 & 12.91 \\
\hline C4 & 13.62 & 11.85 & -29 & 10.29 & -34 & 7.86 & -42 & 6.65 & -39 & 10.05 \\
\hline C5 & 16.52 & 14.35 & -14 & 13.50 & -13 & 13.25 & -2 & 10.06 & -8 & 13.53 \\
\hline C6 & 16.69 & 11.94 & -29 & 10.88 & -30 & 9.67 & -28 & 6.62 & -39 & 11.15 \\
\hline C7 & 14.67 & 10.45 & -38 & 10.09 & -35 & 7.61 & -44 & 6.09 & -44 & 9.78 \\
\hline C8 & 13.07 & 9.97 & 40 & 9.58 & -38 & 7.31 & -46 & 5.86 & -46 & 9.15 \\
\hline Mean & 15.82 & 13.03 & & 12.07 & & 10.40 & & 8.58 & & \\
\hline LSD at 0.0 & CT: & & P: & & $-x($ & .19 & & & & \\
\hline
\end{tabular}

See footnotes of table 3 for treatments description.

Contents of $P$ and $K$ have a wide range, $P$ content ranged from $0.99 \%$ in $\mathrm{C} 1$ at zero day of composting to $1.56 \%$ in $\mathrm{C} 8$ at composting period $f 60$ days, $K$ content ranged from $0.78 \%$ in $\mathrm{C} 1$ at zero day of composting to $1.09 \%$ in C8 at 60 day of composting. Increasing composting period were associated with increases in $P$ and $K$. In C5 $P$ increased from $1.03 \%$ at zero day of composting to $1.24 \%$ after 60 days. While at zero day of composting was $\mathbf{0 . 8 0}$ $\%$. and increased to $0.93 \%$ after 60 days of compositing. Values of RC for $P$ and $K$ were positive and widely varied from one compost to another. Increases in the $P$ and $K$ in compost are attributed with composting period ( Elgezairy, 2016 and Abou Hussien et al., 2017).
Data in Tables 6 and 7 show that, increases in the composts contents of $P$ and $K$ of irradiated organic materials ILL compared with the materials of unirradiated. After $\mathbf{4 5}$ day of composting contents of $P$ and $K$ in $C 1$ and $C 5$ were $0.89 \%$ and reached $0.90,0.93,0.99 \%$ in C2, C3 and C4. Thus, irradiation increase composting process. This shows that RC value was affected by irradiation of $P$ and $K$ after 30 days showed $R C$ of $2,4,7,2$, 4,11 and $14 \%$ for $P$ content were $0,3,6$, 2, 0,7 and $9 \%$ for $K$ content due to $C 2$, C3, C4, C5, C6, C7 and C8 compared with those found in $\mathrm{C} 1$, respectively. These results mean that irradiation of organic residues using gamma rays decreased composting period to obtain on mature compost with a high content of $P$ and $K$. These results are in agreement with those obtained by Liu et al. (2018). 
Table 6: Effect of raw organic materials source and irradiation using gamma rays on produced compost content (\%) of phosphorus (P) and its relative change "RC" (\%) at different composting periods.

\begin{tabular}{|c|c|c|c|c|c|c|c|c|c|c|}
\hline \multirow{3}{*}{$\begin{array}{c}\text { Compost } \\
\text { type } \\
\text { (CT) }\end{array}$} & \multicolumn{9}{|c|}{ Composting period " CP ": (Day) } & \multirow{3}{*}{$\begin{array}{c}\text { Mean } \\
\%\end{array}$} \\
\hline & \multirow{2}{*}{$\begin{array}{l}0 \\
\%\end{array}$} & \multicolumn{2}{|c|}{15} & \multicolumn{2}{|c|}{30} & \multicolumn{2}{|c|}{45} & \multicolumn{2}{|c|}{60} & \\
\hline & & $\%$ & $\begin{array}{c}\text { RC } \\
\%\end{array}$ & $\%$ & $\begin{array}{c}\text { RC } \\
\%\end{array}$ & $\%$ & $\begin{array}{c}\mathrm{RC} \\
\%\end{array}$ & $\%$ & $\begin{array}{c}\text { RC } \\
\%\end{array}$ & \\
\hline C1 & 0.99 & 1.09 & & 1.15 & & 1.19 & & 1.19 & & 1.12 \\
\hline C2 & 1.09 & 1.14 & 4 & 1.18 & 2 & 1.23 & 3 & 1.26 & 6 & 1.18 \\
\hline C3 & 1.11 & 1.15 & 6 & 1.20 & 4 & 1.26 & 6 & 1.41 & 19 & 1.23 \\
\hline C4 & 1.14 & 1.21 & 11 & 1.23 & 7 & 1.35 & 13 & 1.54 & 29 & 1.29 \\
\hline C5 & 1.03 & 1.13 & 3 & 1.18 & 2 & 1.21 & 2 & 1.24 & 4 & 1.16 \\
\hline C6 & 1.11 & 1.16 & 7 & 1.20 & 4 & 1.24 & 4 & 1.30 & 9 & 1.20 \\
\hline C7 & 1.16 & 1.19 & 9 & 1.28 & 11 & 1.35 & 13 & 1.36 & 14 & 1.27 \\
\hline C8 & 1.21 & 1.26 & 16 & 1.31 & 14 & 1.54 & 29 & 1.56 & 31 & 1.38 \\
\hline Mean & 1.10 & 1.17 & & 1.21 & & 1.30 & & 1.36 & & \\
\hline \multicolumn{3}{|c|}{ LSD at $0.05 \mathrm{CT}$} & \multicolumn{2}{|c|}{ CP: 0.02} & \multicolumn{3}{|c|}{ CT $\times C P: 0.05$} & & & \\
\hline
\end{tabular}

See footnotes of table 3 for treatments description.

Table 7: Effect of raw organic materials source and irradiation using gamma rays on produced compost content $(\%)$ of potassium ( $k$ ) and its relative change "RC" (\%) at different composting periods (day).

\begin{tabular}{|c|c|c|c|c|c|c|c|c|c|c|}
\hline \multirow{3}{*}{$\begin{array}{l}\text { Compost } \\
\text { type } \\
\text { (CT) }\end{array}$} & \multicolumn{9}{|c|}{ Composting period " CP ": (Day) } & \multirow{3}{*}{$\begin{array}{c}\text { Mean } \\
\%\end{array}$} \\
\hline & \multirow{2}{*}{$\begin{array}{l}0 \\
\%\end{array}$} & \multicolumn{2}{|c|}{15} & \multicolumn{2}{|c|}{30} & \multicolumn{2}{|c|}{45} & \multicolumn{2}{|c|}{60} & \\
\hline & & $\%$ & $\begin{array}{c}\mathrm{RC} \\
\%\end{array}$ & $\%$ & $\begin{array}{c}\text { RC } \\
\%\end{array}$ & $\%$ & $\begin{array}{c}\text { RC } \\
\%\end{array}$ & $\%$ & $\begin{array}{c}\text { RC } \\
\%\end{array}$ & \\
\hline C1 & 0.78 & 0.83 & & 0.88 & & 0.89 & & 0.89 & & 0.85 \\
\hline C2 & 0.81 & 0.86 & 4 & 0.88 & 0 & 0.90 & 1 & 0.93 & 4 & 0.88 \\
\hline C3 & 0.86 & 0.86 & 4 & 0.91 & 3 & 0.93 & 4 & 0.94 & 5 & 0.90 \\
\hline C4 & 0.83 & 0.91 & 10 & 0.93 & 6 & 0.99 & 11 & 1.06 & 19 & 0.94 \\
\hline C5 & 0.80 & 0.84 & 1 & 0.90 & 2 & 0.89 & 0 & 0.93 & 4 & 0.87 \\
\hline C6 & 0.85 & 0.89 & 7 & 0.88 & 0 & 0.93 & 4 & 0.96 & 8 & 0.90 \\
\hline C7 & 0.89 & 0.90 & 8 & 0.94 & 7 & 0.95 & 7 & 0.99 & 11 & 0.93 \\
\hline C8 & 0.91 & 0.93 & 12 & 0.96 & 9 & 1.06 & 19 & 1.09 & 22 & 0.99 \\
\hline Mean & 0.84 & 0.88 & & 0.91 & & 0.94 & & 0.97 & & \\
\hline \multicolumn{11}{|l|}{ LSD at 0.05} \\
\hline
\end{tabular}

See footnotes of table 3 for treatments description.

$P$ and $K$ shown in Tables 6 and 7 were indicate variation between composted organic residues. At all composting periods, $P$ and $K$ contents in the composts produced only from LL were lower than those presence in the composts produced from the mixture of LL, PM and SB. This is attributed to high content of $P$ and $K$ in this mixture due to high contents of nutrients in PM 
(Kononava, 1966). Gohar (2011) mentioned that, $P$ and $K$ in compost depend on the source of the composted organic materials and its chemical composition. These results are in agreement with those obtained by Liu et al (2018).

\section{REFERENCES}

Abou-Hussien, E. A., M. N. Faiyad, W. M. Nada and M. Kh. Elgezery (2016). Effect of sulphur additives on the chemical composition of compost. Menoufia J. Soil Sci., 1(December): 177-189.

Abou-hussien, E. A., W. M. Nada and M. Kh. Elgezery (2017). Evaluation efficiency of sulfur fertilizer in calcareous soil amended by compost. Menoufia J. soil science, 2 (February): 59-72.

Alexander, R. (2001). Compost utilization in landscapes. In: Stoffel P.J., Kahn B.A. (eds.): Compost utilization in horticultural cropping systems. Lewis Publ. N Y .

Coutinho, J., M. Arrobas and 0 . Rodrigues (1997). Effect of composted sewage sludge amendment on soil nitrogen and phosphorus availability. Commun. Soil Sci. PI Anal. 28(1920): 1845-1857.

Elgezery, M. Kh. (2016). Effect of organic addition on efficiency of sulphar fertilization.M. sc. Thesis. Fac. of Agric., Menoufia Univ., Egypt.

Elvira, C., L. Sampedro, E. Benitez and R. Nogales (1998). Vermicomposting of sludges from paper mill and dairy industries with Eisenia andrei: a pilotscale study. Bio res. Tech. 63: 205211.

Fan, Y. V., C. T. Lee, J. J. Klemes, L. S. Chua, M. R. Sarmidi and C. W. Leow (2018). Evaluation of effective microorganisms on home scale organic waste composting. J. of Environ. Manage. 216: 41 - 48.
Gohar, H. M. A. (2011). Effect of some plant residues on soil properties and plant growth in newly reclaimed soils. M. Sc. Thesis, Fac. of Agric., Minoufiya Univ., Egypt.

Hagemann, N., Subdiaga, E. Orsetii, J. M. de la Rosa, H. Knicker, H. H. Schmidt, A. Kappler and S. Behrens (2018). Effect of biochar amendment of compost on organic composition following aerobic composting of manure. Sci Tot Environ. 613 - 614:2029.

He, Z.L., A.K. Alva, P. Yan, Y.C. Li, D.V.S.P.J. Calvert and D.J. Banks (2000). Nitrogen mineralization and transformation from composts and biosolids during field incubation in a sandy soil. Soil Sci. 165:161-169.

He, X.T., T.J. Logan and S.J. Train (1995). Physical and chemical characteristics of selected U.S. municipal solid waste composts. Journal of Environ. Qual. 3: 543-552.

He, Z., X. Yang, B.A. Kahn, P.J. Stoffel and D.V. Calvert (2001). Plant nutrition benefits of phosphorus, potassium, calcium, magnesium, and micronutrients from compost utilization. In: Stoffella P.J., Kahn B.A. (eds.): Compost utilization in horticultural cropping systems307323. Lewis Publishers, N Y, USA.

Iqbal, H., M. Garcia-Perez, M. Flury (2015). Effect of biochar on leaching of organic carbon, nitrogen, and phosphorus from compost in bioretention systems. Science Tot Environ. 521-522: 37-45.

Jain, M.S., R. Jambhulkar and A.S. Kalamdhad (2018). Biochar amendment for batch composting of nitrogen rich organic waste: Effect on degradation kinetics, composting physics and nutritional properties. Biores Tech. 253: 204-213.

Khaalil, Z. M., M. F. Tantawy and M. A. H. Mohamad (2015). Effect of cobalt 
application on yield and yield components of wheat grown under two intervals of irrigation. Menoufia $\mathrm{J}$. Agric. Res., $40: 239-261$.

Khaalil, Z. M., M. F. Tantawy and M. A. H. Mohamad (2015). Effect of cobalt application on yield and yield components of wheat grown under two intervals of irrigation. Menoufia $\mathrm{J}$. Agric. Res., 40 : $239-261$.

Kononova, M.M. (1966). Soil organic matter. Its role in soil formation and in soil fertility. Oxford, Perganom Press, Academy of Science, USSR.

Lee, A. (2016). Nitrogen and phosphorus availability from various composted wastes for use in Irish agriculture and horticulture. PhD Thesis. Dublin Institute of Technology, KevinStree School of Chemical and Pharmaceutical Sciences.

Liu, X., M. Rezaei Rashti, A. Dougall, M. Esfandbod, L. Van Zwieten and C. Chen (2018). Subsoil application of compost improved sugarcane yield through enhanced supply and cycling of soil labile organic carbon and nitrogen in an acidic soil at tropical Aust. Soil Tillage Res. 180: 73-81.

Lu, Q., Y. Zhao, X. Gao, J. Wu, H. Zhou, P. Tang, Q. Wei and Z. Wei (2018). Effect of tricarboxylic acid cycle regulator on carbon retention and organic component transformation during food waste composting. Biores. Tech. 256:128-136.

Marschner, H. (1995). Mineral nutrition of higher plants. 2nd Ed. Academic Press, N Y. USA.

Nada, W. M.A. (2011). Wood compost process engineering, properties and its impact on extreme soil characteristics. Ph.D. Thesis, Faculty of Mathematics and Natural Sciences, Potsdam University, Germany.
Sisouane, M., M. M. Cascant, S. Tahiri, S. M. Garrigues, G. E. K. Boutchich, M. L. Cervera and M. De la Guardia (2017). Prediciction of organic carbon and total nitrogen contents in organic wastes and their composts by Infrared spectroscopy and partial least square regression Talanta 167: 352- 358.

Sisworo, E. L., D. L. Eskew, W. H. Resjidand- Sisworo, H. Kadarusman, H. Solahuddin and G. Soepadi (1990). Studies on the availability of Azola $\mathbf{N}$ and urea for rice growth using $\mathrm{N}^{15}$ plant and soil. 128: 209.

Sisworo, E. L., D. L. Eskew, W. H. Resjidand- Sisworo, H. Kadarusman, H. Solahuddin and G. Soepadi (1990). Studies on the availability of Azola $\mathrm{N}$ and urea for rice growth using $\mathrm{N}^{15}$ plant and soil. 128: 209.

Stevenson, F.J. (1994). Humus Chemistry: Genesis, Composition, Reactions.Wiley-Interscience, New York.

Vogtmann, H., H. Fricke and T. Turk (1993). Quality, physical characteristics, nutrient content, heavy metals and organic chemicals in biogenic waste compost. Compost Science \& Utilization 1(4): 69-87.

Warman, P.R. and M.J. Anglopez (2002). The chemical properties of vermicompost derived from different feedstocks. Proc Intl Composting and Compost Sci Symposium, Columbus, Ohio: CD Rom.

Zwart, K. (2003). Fate of C and N pools experience from short and long term compost experiments. In: Anon., Applying composts benefits and needs, Brussels, Federal Ministry of Agriculture, Forestry, Environment and Water Management, Austria, and European Communities, 77-86. 


\section{استخدام تقنيه التشعيع باشعه جاما لتحسين جوده الكمبوست}

الحسيني عبد الغفار ابو حسين(")، بلر يوسف الكومي(')، عزت عبد المحسن قطب(†)،

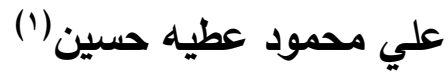

(1) قسم علوم الاراضي - كليه الززاعه - جامعه المنوفيه - مصر

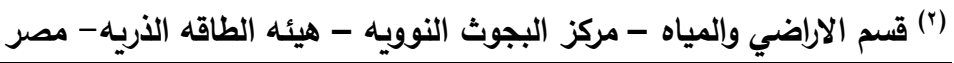

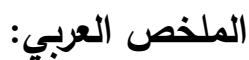

اجريت هذه الدراسه فى قسم بحوث الأراضي والمياه - مسركز البحوث النوويه - هيئه الطاقه الذريه لاراسه تاثير

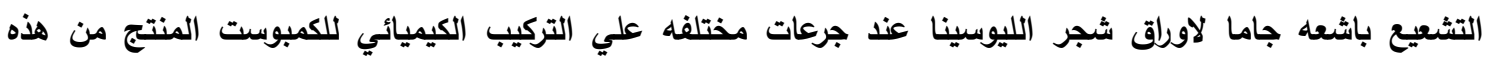

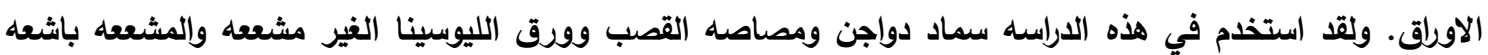

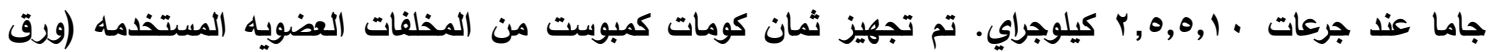

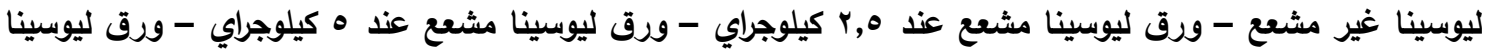

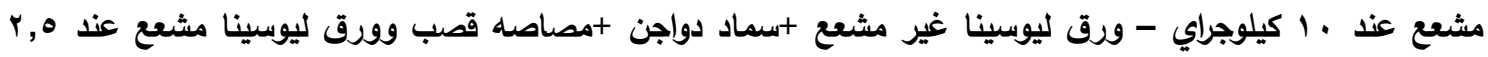

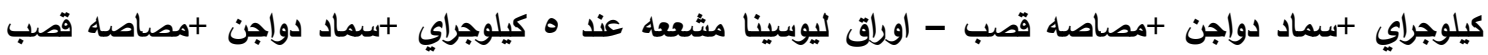

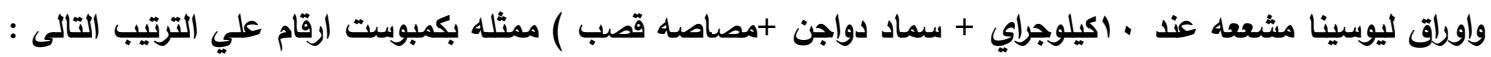
(C1,C2,C3,C4, C5,C6,C7)

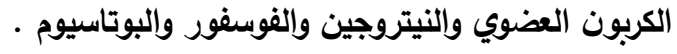

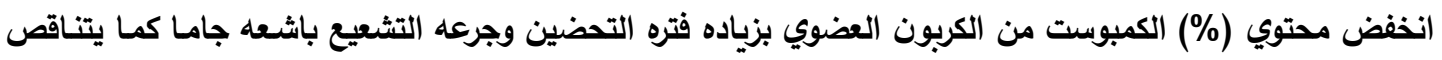

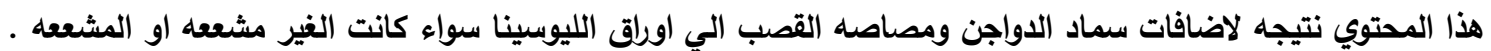

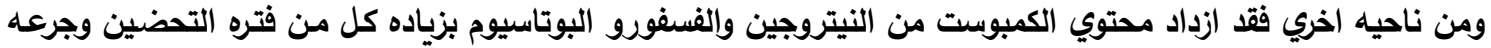

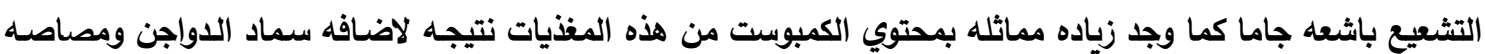
القصب الي اولق الليوسينا الحيثه سواء الغير مشععه او المشععه . 
